\title{
In Situ Bioremediation Using Horizontal Wells
}

\section{INNOVATIVE TECHNOLOGY SUMMARY REPORT}

\section{demonstrated at}

\section{U.S. Department of Energy M. Area}

Savannah River Site Aiken, SC

\section{prepared for}

U.S. Department of Energy

Office of Environmental Management

Office of Technology Development

\section{April 1995}




\section{DISCLAIMER}

Portions of this document may be illegible in electronic image products. Images are produced from the best available original document. 


\section{TABLE OF CONTENTS}

1 SUMMARY

page 1

2 TECHNOLOGY DESCRIPTION

page 3

3 PERFORMANCE

page 4

4 TECHNOLOGY APPLICABILITY \& ALTERNATIVES

page 8

$5 \cos T$

page 9

6 REGULATORY/POLICY ISSUES

page 11

7 LESSONS LEARNED

page 13

\section{APPENDICES}

A Demonstration Site Characteristics

B Technology Description Detail

C Performance Detail

D Commercialization/ntellectual Property

E References 


\section{SECTION 1}

\section{SUMMARY}

\section{Technology Description}

In Situ Bioremediation (ISB), which is the term used in this report for Gaseous Nutrient Injection for In Situ Bioremediation, remediates soils and ground water contaminated with volatile organic compounds (VOCs) both above and below the water table. ISB involves injection of air and nutrients (sparging and biostimulation) into the ground water and vacuum extraction to remove.VOCs from the vadose zone concomitant with biodegradation of VOCs.

The innovation is in the combination of 3 emerging technologies: air stripping, horizontal wells, and bioremediation via gaseous nutrient injection with a baseline technology, soil vapor extraction, to produce a more efficient in situ remediation system.

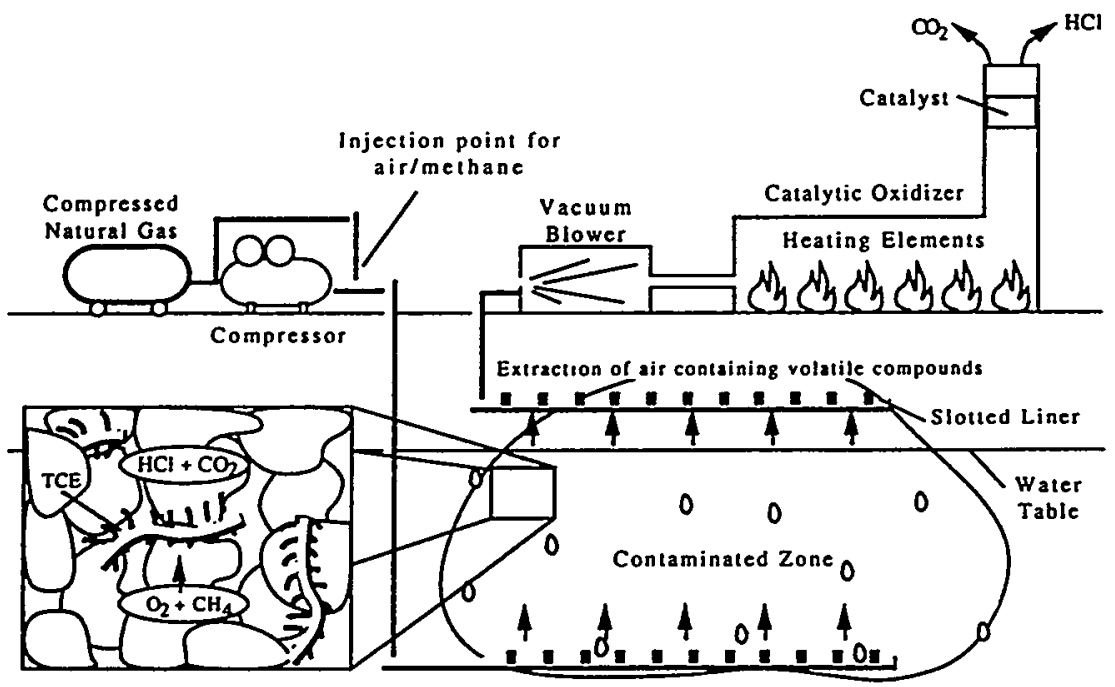

- Horizontal wells provide a more effective access to subsurface contamination.

- The air sparging/gaseous nutrient injection process eliminates the need for surface ground water treatment systems and treats the subsurface, both unsaturated and saturated zones, in situ.

- The air sparging/gaseous nutrient injection process stimulates the growth of indigenous microorganisms in the contaminated zone to degrade and mineralize VOCs. Soil vapor extraction can be combined with the injection process to strip the higher concentration, more easily removed contaminants from the subsurface. The injection/extraction system can be designed to meet site specific needs.

- The types of sites most likely to apply ISB will contain moderately permeable, relatively homogenous sediments contaminated with VOCs, especially if both an extraction and injection component is utilized. However, the presence of clay strata does not preclude its use. In fact, the bioremediation component may be well applied to enhance degradation and/or removal of VOCs from lower permeability zones. 
Technology Status

A full-scale demonstration was conducted as part of the Savannah River Integrated Demonstration: VOCs in Soils and Ground Water at Nonarid Sites.

U.S. Department of Energy

Savannah River Site

M Area Process Sewer/Integrated Demonstration Site

Aiken, South Carolina

February 1992 to April 1993

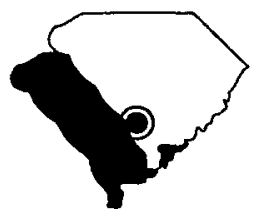

- A group of nationally recognized experts from the U.S. Department of Energy (DOE), the U.S. Air Force, the U.S. Geological Survey, the U.S. Environmental Protection Agency, industry, and academia met regularly for 3 years to provide unique insights for planning, execution, and evaluation of this technology demonstration.

The demonstration site was located at one of the source areas within the one-square mile VOC ground water plume. Prior to application of ISB, trichloroethylene (TCE) and tetrachloroethylene (PCE) concentrations in ground water ranged from 10 to $1031 \mathrm{ug} / \mathrm{L}$ and 3 to $124 \mathrm{ug} / \mathrm{L}$, respectively. TCE and PCE concentrations in sediments ranged from 0.67 to $6.29 \mathrm{mg} / \mathrm{kg}$ and 0.44 to $1.05 \mathrm{mg} / \mathrm{kg}$. The site is underlain by a thick section of relatively permeable sands with thin lenses of clayey sediments. Appendix A describes the site in detail.

\title{
Key Results
}

- Almost $17,000 \mathrm{lbs}$. of VOCs were removed or degraded over 384 days of operation. The vacuum component of ISB removed $12,096 \mathrm{lbs}$. VOCs and the biological component degraded and mineralized an additional 4,838 lbs. VOCs.

- Mass balance calculations indicate that bioremediation destroyed $40 \%$ more VOCs than simple air sparging (i.e, in situ air stripping).

- Gaseous nutrient injection of carbon, nitrogen, and phosphorus was achieved simultaneously for the first time and demonstrated better mass transfer than previous methods of liquid nutrient injection.

- This nutrient injection strategy stimulated a specific functional group of bacteria that is known to degrade specific contaminants.

- No toxic intermediates were produced by the bioremediation strategy. Contaminants were completely mineralized.

- The best operating campaign used continuous air and nutrient injection (N \& P) plus the pulsed addition of $4 \%$ methane.

- Los Alamos National Laboratory (LANL) completed a cost-benefit analysis showing that ISB could reduce costs by over $30 \%$ compared to the baseline technology of an integrated Soil Vapor Extraction/Pump- and-Treat System (SVE/PT).

- ISB could reduce the time required to remediate a site by 5-7 years compared to the baseline technology of SVE/PT.

The ISB process is patented by the Department of Energy and has been licensed to six commercial vendors with 13 new applications pending. Two companies are using the technology in the field. Licenses are available through the Westinghouse Savannah River Company (WSRC).

\section{Contacts}

\section{Technical}

Terry Hazen and Brian Looney, Principal Investigators, WSRC, (803) 725-6413 and (803) 725-3692.

\author{
Management \\ Kurt Gerdes, DOE EM-50, DOE Integrated Demonstration Program Manager, \\ (301)903-7289.
}

Jim Wright, DOE Plumes Focus Area Implementation Team Manager, (803)725-5608.

\section{Licensing Information}

Caroline Teelon, Technology Transfer Office, WSRC, (803)725-5540.

Page 2 


\section{TECHNOLOGY DESCRIPTION}

\section{Overall Process Schematic}

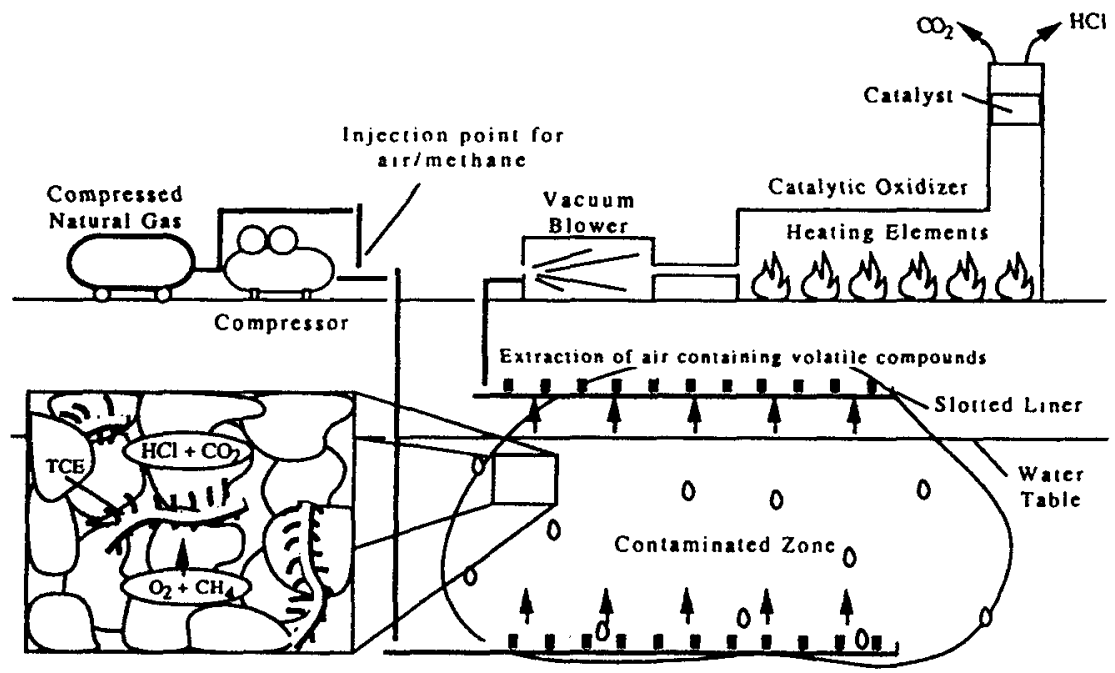

- Air, methane, nitrous oxide, and triethyl phosphate were injected through the lower horizontal well, below the water table.

- An air/contaminant mixture was extracted from the upper horizontal well, above the water table.

- Offgas treatment used catalytic oxidation for the demonstration, but other technologies are available for the treatment of offgases.

- Indigenous methanotrophic bacteria can oxidize methane via a series of enzymes (e.g., methane monooxygenase). Methane monooxygenase, an extremely powerful oxidizer, induces the formation of TCE-epoxide from TCE. TCE epoxide is extremely unstable and spontaneously breaks down. The final and almost immediate end product is carbon dioxide and chloride salts.

Appendix B provides detailed information about the horizontal well installations and the monitoring wells installed.

\section{Aboveground System}

Notes:

*Air-water separator removes debris and moisture from the air stream. System includes a day tank to drain water from separator for treatment at $M$ Area air stripper.

**Demonstration generated VOCs that were treated by electrically heated catalytic oxidation of the offgas.

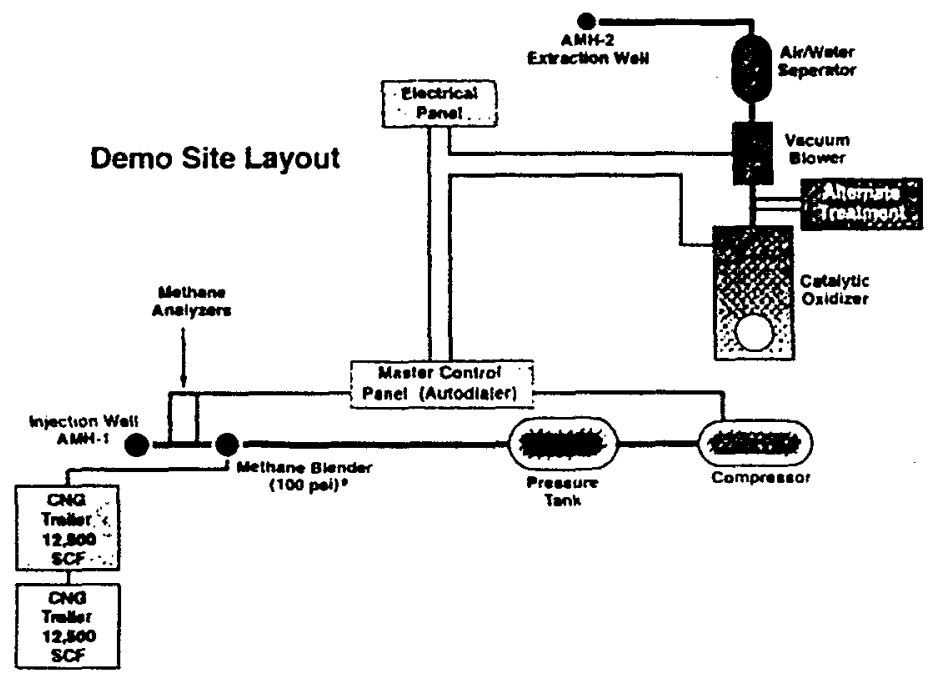

Process Schematic and Fingineering Schematic 


\section{SECTION 3}

\section{PERFORMANCE}

\section{Demonstration Plan}

- Performance of the technology has been assessed using information from the full-scale demonstration at SRS. Six different operational modes were tested during the demonstration.

- Major elements of the demonstration included:

- initial vapor extraction of vadose zone gases (20 days),

- addition of air sparging by simultaneous air injection into the saturated zone and vapor extraction from the vadose zone ( 33 days),

- a planned series of nutrient additions:

- $1 \%$ methane addition (107 days),

- $4 \%$ methane addition ( 79 days),

- pulsed $4 \%$ methane addition operated at long and short intervals (94 days),

- continuous addition of gaseous nutrients in the form of $0.07 \%$ nitrous oxide and $0.007 \%$ triethyl phosphate in air in combination with pulses of $4 \%$ methane ( 94 days).

- assessment of the behavior of injected methane in air through an inert gas (helium) tracer test, and

- comparison of microbiological assays for monitoring and control of in situ bioremediation.

\section{Treatment Performance}

\section{Summary}

- Air-nutrient injection/extraction removed VOCs from the subsurface and degraded VOCs in place.

- Biostimulation and biodegradation occurred in situ without producing toxic daughter products.

- Increases in indigenous methanotrophs and in $\mathrm{CO} 2$ concentrations in soil gas and extraction well gas imply significant microbial community degradation of methane and TCE.

- Decreases in methane and TCE in the subsurface coincided with increases in densities of methanotrophs (up to 7 orders of magnitude) and free chloride ion as a result of biodegradation.

- Addition of continuous $4 \%$ methane initially stimulated microbial populations but led to nutrient depletion, which then decreased the microbial population.

- Addition of nitrogen and phosphorus nutrients with pulsed methane resulted in enhanced and sustained microbial growth that optimized bioremediation and mineralization of TCE and PCE in ground water and sediments.

- ISB has demonstrated reduction of VOC concentrations in ground water below the Safe Drinking Water Act maximum of $5 \mathrm{ppb}$ for TCE/PCE. Overall ground water concentrations decreased by as much as $95 \%$.

- Cleanup of VOCs in the vadose zone was very effective. Most sediments contained nondetectable concentrations of VOCs after the demonstration was completed. Soil gas concentrations decreased by more than $99 \%$.

- Average daily emissions from the offgas stream were less than the minimum detection of $1.9 \mathrm{lb} . /$ day. Greater than $94 \%$ of VOCs were treated by the catalytic oxidation unit.

\section{Key System Parameters}

- Horizontal Well Placement

- The lower injection horizontal well was placed below the water table (120 feet) at a depth of 175 feet with a screened length of 310 feet.

- The upper extraction horizontal well was placed in the vadose zone above the water table at a depth of 80 feet with a screened length of 205 feet.

- Vacuum Applied

- Air was extracted continuously from the upper vadose zone horizontal well (AMH-2) at $240 \mathrm{scfm}$.

- Air Injection

- Air plus nutrients were injected into the lower aquifer horizontal well (AMH-1) at $200 \mathrm{scfm}$.

- Nutrient Injection Campaigns

- $1 \%$ methane was initially injected continuously.

- Methane concentration was increased to $4 \%$. 
- Methane injection was maintained at $4 \%$ but it was applied in pulses.

- Pulsed $4 \%$ methane injection was supplemented with continuous injection of $0.07 \%$ nitrous oxide and $0.007 \%$ triethyl phosphate in air to supply nitrogen and phosphate required for sustained microbial growth and metabolism.

- Microbial Activity

- Prior to ISB, subsurface ground water and vadose zone bacterial populations were low, and the microbial population was under nutrient stress.

- The addition of methane specifically stimulated the growth of methanotrophs, the bacteria primarily responsible for degradation of TCE.

\section{Biostimulation}

- Evidence of biostimulation: densities of methanotrophs and methylotrophs in the ground water increased as TCE decreased.

\section{Amount of VOCs Removed or Degraded in Place}

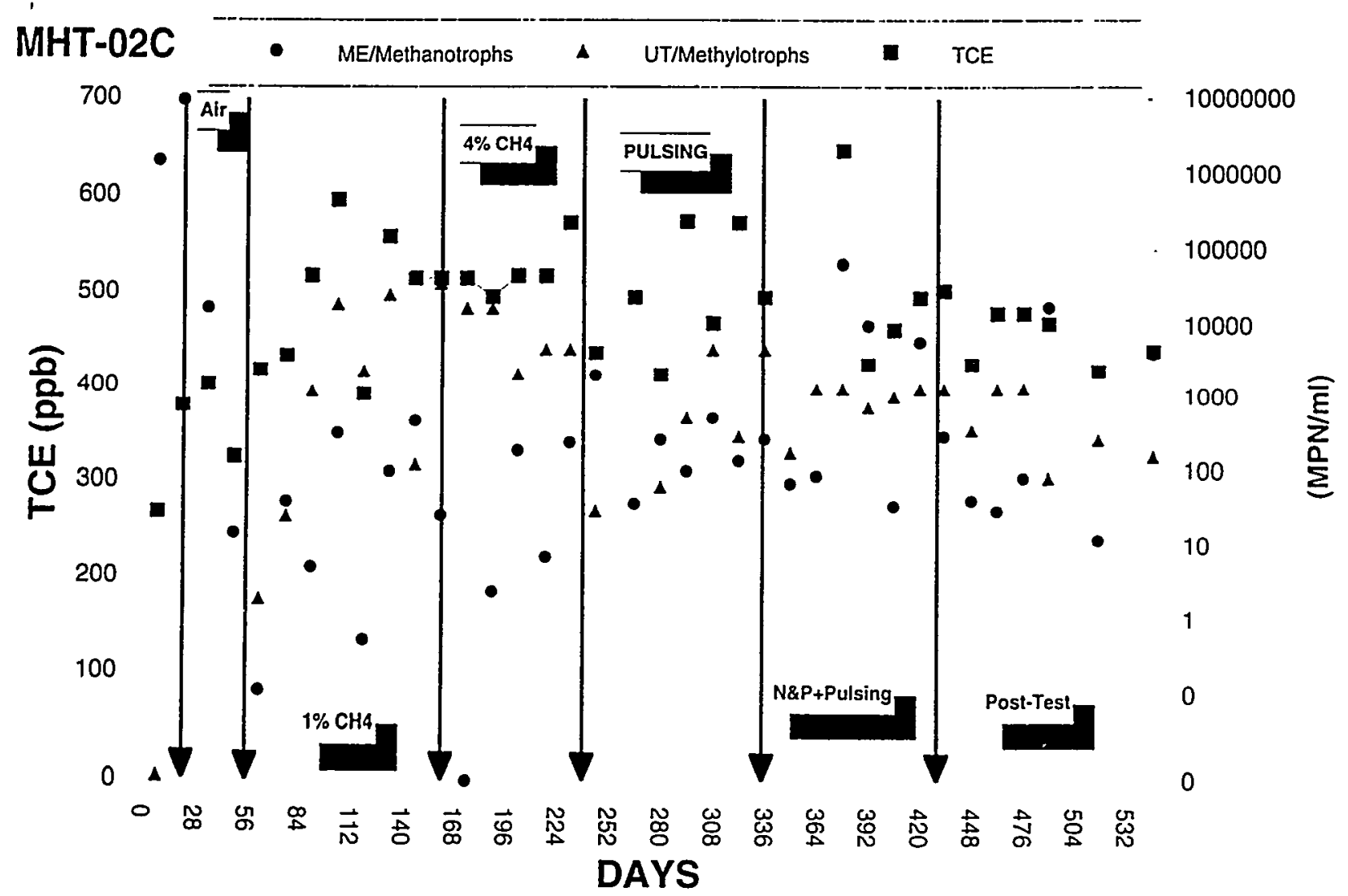

- Almost $17,000 \mathrm{lbs}$. of VOCs were removed over 384 days of operation.

- The vacuum component of ISB removed 12,096 Ibs. VOCs and the biological component degraded and mineralized an addjtional 4,838 lbs. VOCs. Figures showing the concentrations of TCE and PCE in the sediments before and after the demonstration (following) were used to calculate the mass degraded in place. 


\section{Concentration of TCE in Sediments Before and After ISB}
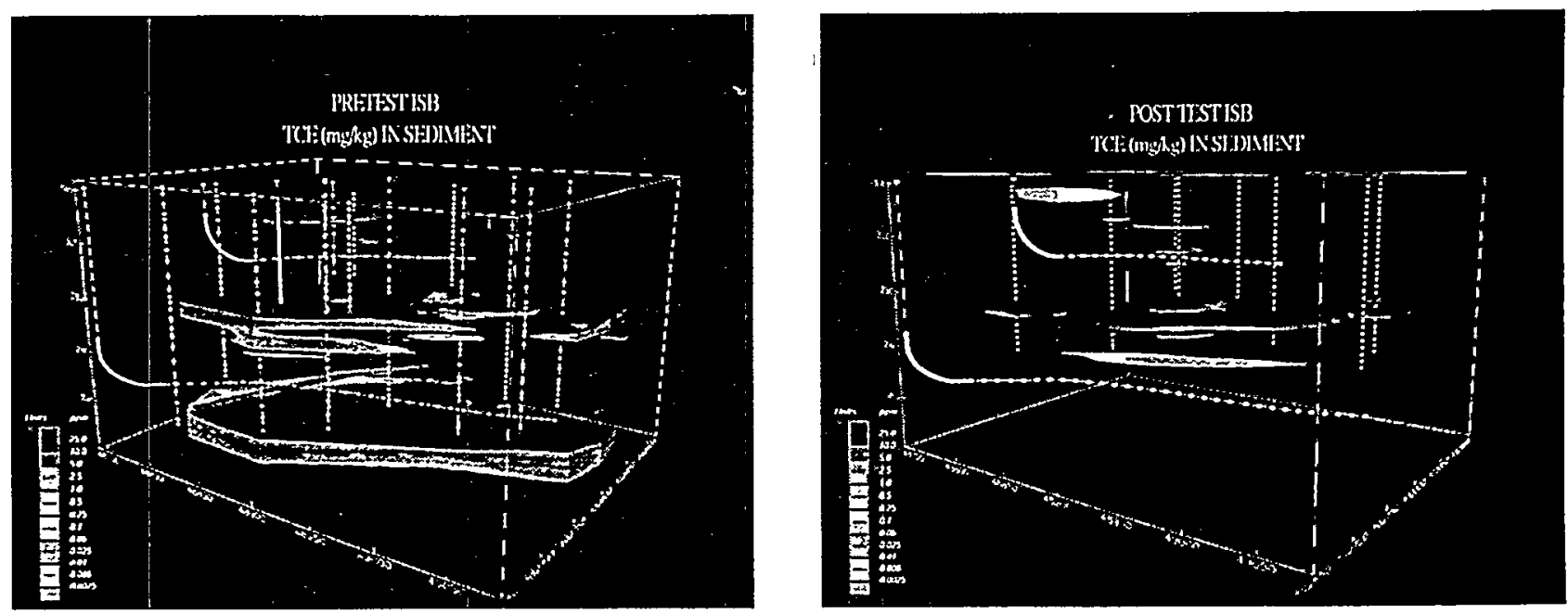

- Sediment data are known to underestimate the amount of VOCs at the demonstration site, but can be used to develop a sense of relative amounts of contamination removed or degraded in place during the demonstration.

- The total sediment inventory for both TCE and PCE decreased by $24 \%$.

\section{Concentration of PCE in Sediments Before and After ISB}
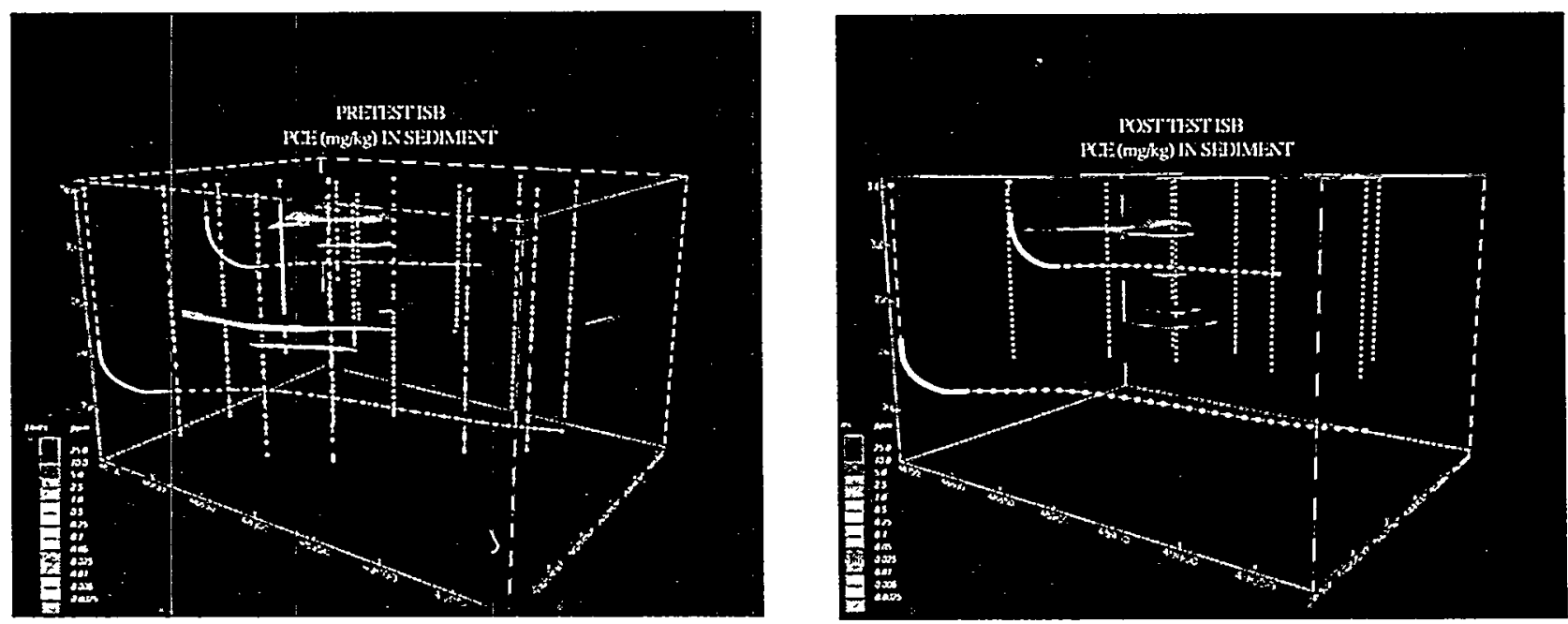

- Sediment data are known to underestimate the VOCs at the demonstration site, but can be used to develop a sense of relative amounts of contamination removed or degraded in place during the demonstration.

- The total sediment inventory for both TCE and PCE decreased by $24 \%$. 


\section{Results of Helium Tracer Test}

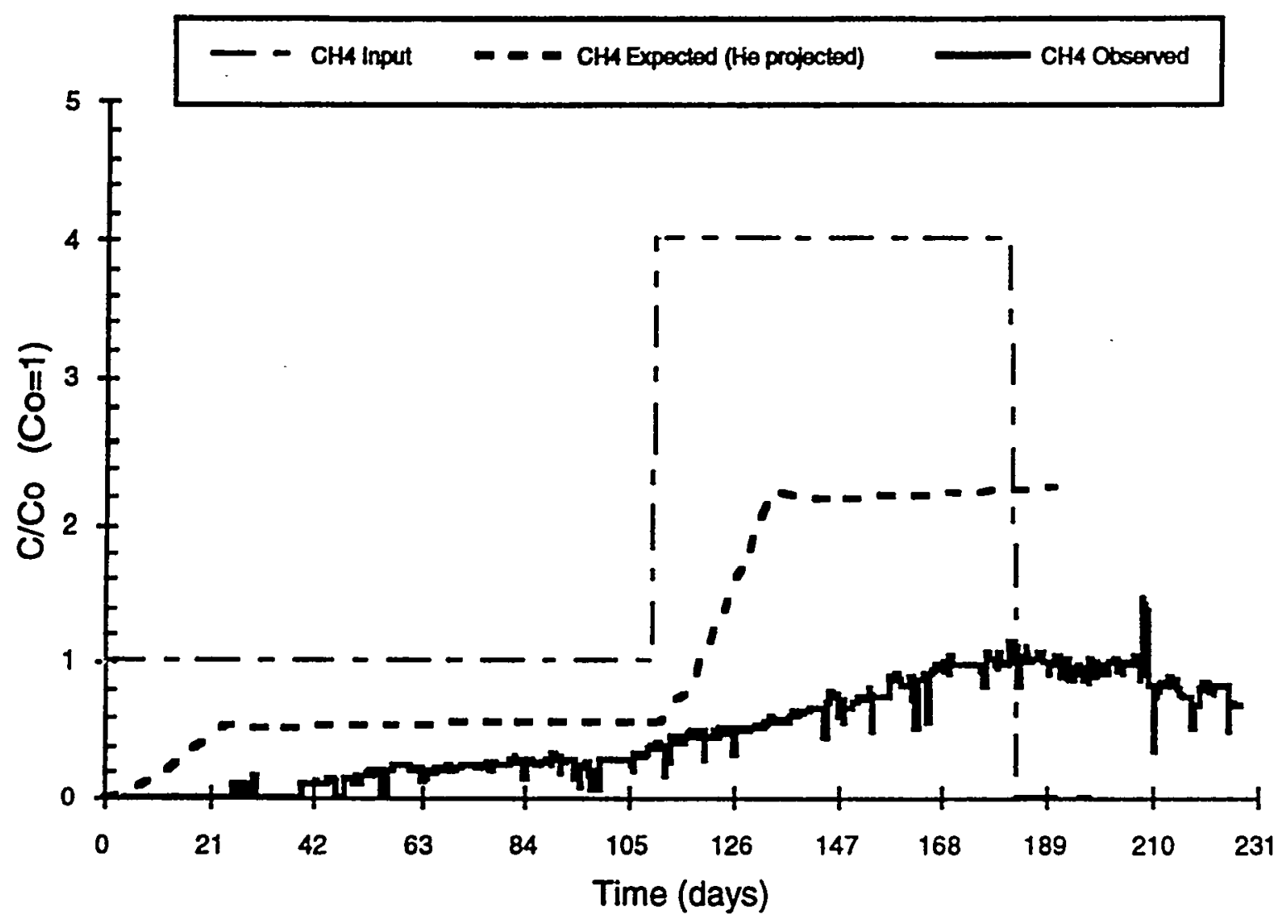

Actual and Predicted Methane Based Upon Helium Tracer Over Time

- A helium tracer test was used to predict the fate of the injected methane.

- Based on helium breakthrough curves, the amount of methane that should have been observed in the extraction well was calculated.

- More than $50 \%$ of the injected methane was removed before it reached the extraction well.

- Microbial metabolism consumed the methane that did not reach the extraction well.

\section{Zones of Influence}

- The extraction well in the vadose zone created a zone of influence estimated to be greater than $200 \mathrm{ft}$ based on pressure measurements.

- Electrical resistance tomography was used to map a sparge zone of influence in the saturated zone. These data showed that flow paths were confined to a complex three-dimensional network of channels, some of which extended as far as 100 feet from the injection well.

- Methane was detected at distances over 500 feet from the injection well. 


\section{SECTION 4}

\section{TECHNOLOGY APPLICABILITY AND ALTERNATIVE TECHNOLOGIES}

\section{Technology Applicability}

- ISB via Gaseous Nutrient Injection has been demonstrated to remediate soils, sediments, and ground water contaminated with VOCs both above and below the water table. The gaseous nutrient injection system can be designed for application only in the unsaturated zone as an add-on to the bioventing process.

- The geometry of horizontal well treatment conforms to typical subsurface contaminated zones, which are often relatively thin but laterally extensive areas.

- ISB is not well suited for extremely low permeability sites if injection and extraction is utilized. Some permeability is required to deliver the nutrients to the indigenous microorganisms.

- At some sites ISB could be most effective when used in conjunction with in situ air stripping, that is in situ air stripping is applied first at a site to quickly remove high concentrations of contaminants from source areas and then ISB is applied as a polishing step to remove contaminants present at lower concentrations. At other sites ISB only would be utilized, thus minimizing the amount of contaminants removed from the subsurface needing treatment as offgas at the surface.

- ISB has demonstrated that it can clean up ground water to drinking water standard concentrations. Sufficient information on cleaning up an entire site to these standards is not available.

- Commercialization and intellectual property information is included in Appendix D.

\section{Competing Technologies}

- ISB with Gaseous Nutrient Injection is competitive with conventional baseline technologies of pump-and-treat and pump-and-treat combined with soil vapor extraction. Numerous other physical/chemical, thermal, and biological technologies are also either available or under development to treat VOC-contaminated soils and ground water either in situ or above ground.

- The effectiveness of ISB was compared with performance data from air sparging and soil vapor extraction alone (VOCs removed through the offgas treatment system). This comparison was used as the basis of the cost analysis discussed in Section 5 .

- Air sparging in vertical wells and in well recirculation technologies have been implemented at similar sites across the U.S. and in Europe. Thermal technologies have more often been applied at sites with less permeable sediments. Deep soil mixing has been applied at sites with shallower contamination.

\section{Technology Maturity}

- Stimulation of indigenous methanotrophic bacteria by injection of methane in water was demonstrated at a small sandy field site at Moffett Field in California, forming the technical basis for the design of this demonstration. However, the Moffett Field demonstration involved addition of nutrients as liquids rather than gases. The SRS demonstration was the first gaseous nutrient injection demonstration designed for stimulation of methanotrophs.

- Much laboratory and bench-scale work has been completed to verity the technical basis for the demonstration.

- ISB via Gaseous Nutrient Injection is currently being applied at two industrial sites and is planned for implementation at the Savannah River Site Sanitary Landfill and the M-Area Integrated Demonstration Site. It has also been proposed at a number of other industrial sites.

- A market survey on horizontal environmental wells was completed in 1993. Key results of that study included:

- Since 1987, over 100 horizontal environmental wells have been installed in the U.S.

- $25 \%$ of the wells have been used for ground water extraction, $25 \%$ for soil vapor extraction, and $50 \%$ for other purposes, such as air injection, bioventing, and petroleum recovery.

- $80 \%$ of the horizontal wells have been installed at vertical depths of 25 feet or less.

- The rate of horizontal well installations has increased significantly in the last two years possibly because of more widespread recognition of advantages and improvements in drilling techniques, which have made installation more cost effective. A cursory update of the 1993 survey has shown that between July 1993 and December 1994 more than 50 horizontal environmental wells were installed. 


\section{SECTION 5}

\section{COST}

\section{Introduction}

- Information in this section was prepared from data provided by the SRS VOCs in Soils and Ground Water at Non-arid Sites Integrated Demonstration to the Los Alamos National Laboratory, tasked by the DOE Office of Technology Development to perform an independent cost analysis of the technology being demonstrated.

- The mass of contaminant removed or degraded by in situ biological processes is difficult to quantify.

- Mass balance determinations relied upon data collected by sampling and analyzing sediment, air, and ground water samples, and by contaminant plume modeling.

- The conventional technology of integrated pump and treat combined with soil vapor extraction (PT/SVE) was used as the baseline technology, against which ISB was compared. To compare the two remediation systems, a number of assumptions were made:

- PT/SVE would remove the same amount of VOCs as the vacuum component of ISB when operated for the same time period.

- 4 vertical SVE and 1 PT wells would have the same zone of influence as 2 horizontal wells used for ISB.

- Volatilized contaminants from both technologies are sent to a catalytic oxidation system for destruction.

- Capital equipment costs are amortized over the useful life of the equipment, which is assumed to be 10 years, not over the length of time required to remediate a site.

\section{Capital Costs}

- Capital costs for the baseline technology are comparable with the innovative technology of ISB.

- The cost to install horizontal wells for ISB exceeds installation costs of vertical wells. However, horizontal drilling costs are decreasing as the technology becomes more widely used and accepted. If horizontal wells can clean a site faster, significant dollars will be saved on operating costs.

- Fixed equipment costs for ISB include gas mixing and injection equipment for providing the nutrients required for stimulation of the bioremediation portion of the innovative technology.

\begin{tabular}{|c|c|c|}
\hline Capital Costs & ISB & PT/SVE \\
\hline Site Cost & $\$ 5,400$ & $\$ 7,500$ \\
Equipment Cost & $\$ 9200$ & $\$ 32,000$ \\
Design and Engineering $\$ 1$ & $\$ 18,000$ & $\$ 18,000$ \\
Mobile Equipment & $\$ 183,000$ & $\$ 50,690$ \\
Well Installation & $\$ 183,732$ & $\$ 168,665$ \\
Other Fixed Equipment & $\$ 43,075$ & $\$ 64,613$ \\
Mobilization Cost & $\$ 452,407$ & $\$ 341,468$ \\
Total Capital Equipment and & & \\
Mobilization Costs & & \\
\hline
\end{tabular}

\section{Operating Costs}

- The annual operating costs are comparable between the baseline and the innovative remediation technology.

- However, the treatment time is estimated to be 10 years to remediate the demonstration site using the baseline PT/SVE and only 3 years using ISB. Actual treatment times, are estimates and field experience indicates that the PT/SVE estimate is on the optimistic side, when the objective is the Safe Drinking Water Act (SDWA) maximum of $5 \mathrm{ppb}$ for TCE/PCE. 


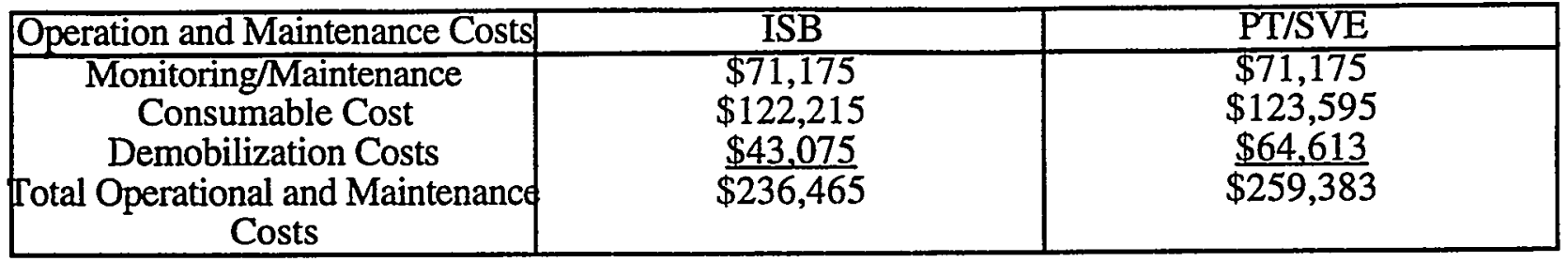

- Consumable and labor costs are approximately $85 \%$ of the total cost per pound of the VOCs remediated for both technologies.

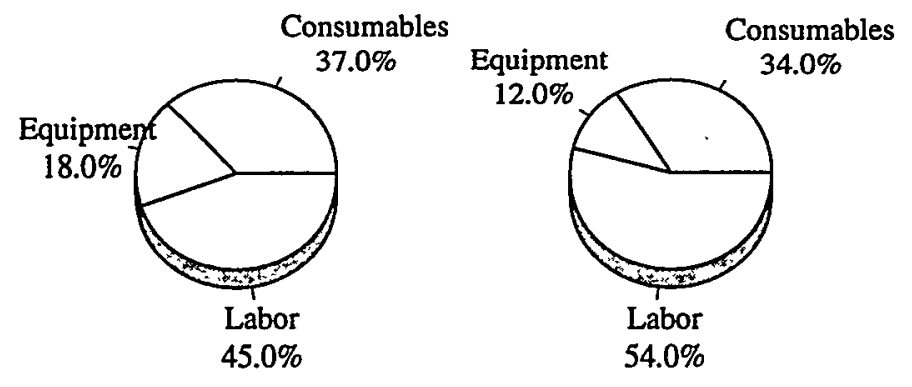

ISBR (\$21/1b Remediated) $\quad$ PT/SVE $(\$ 31 / L B$ Remediated $)$

- The length of time that the ISB system operated determines the quantity of VOCs remediated. The demonstration was operated for 384 days.

- Mass balances calculated that $41 \%$ more VOC destruction occurred with ISB than with air sparging (using the same operating parameters) because of biological remediation.

- A model developed by LANL during the demonstration predicts that after 3 years the quantity remediated would have been $90 \%$.

- The worst case scenario would be no additional destruction because of biological stimulation, but this would still produce a reduction in remediation cost over the baseline technology.

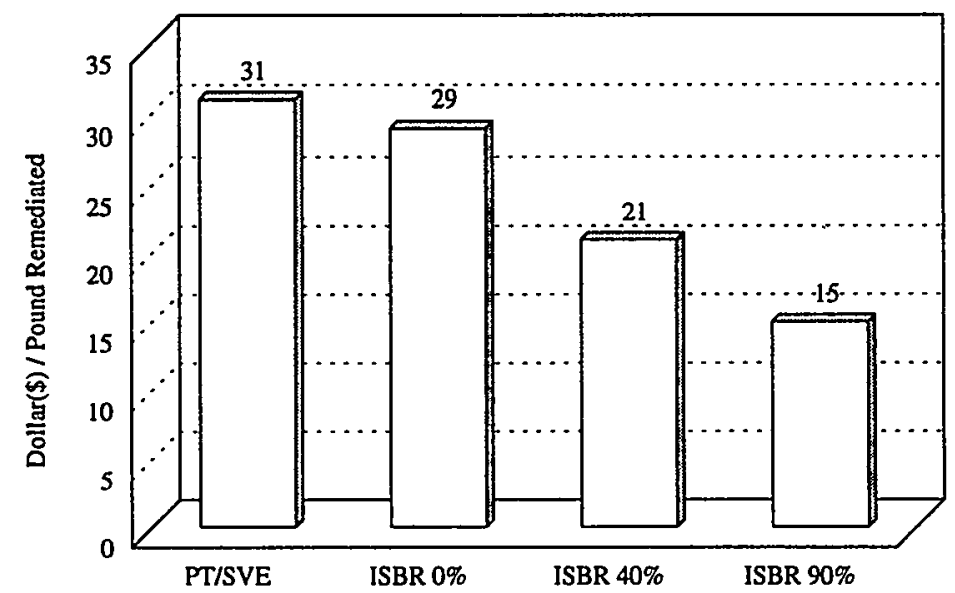




\section{SECTION 6}

\section{REGULATORY/POLICY ISSUES}

\section{Regulatory Considerations}

- Permit requirements for the demonstration were controlled by the South Carolina Department of Health and Environmental Control (SCDHEC) and included 1) an Air Quality Permit and 2) an Underground Injection Control (UIC) Permit issued by the South Carolina Board of Drinking Water Protection. A NEPA checklist was also prepared; a categorical exclusion was granted. U.S. Department of Transportation (DOT) certification was required to transport methane to the remediation site.

- Permit requirements for future applications of ISB are expected to include:

- An air permit for discharge of treated vapor extracted from the subsurface,

- CERCLA and/or RCRA permitting depending on site specific requirements,

- Underground injection permits for the injection of methane and nutrients into the subsurface,

- NEPA review for federal projects, and

- U.S. DOT certification for transportation of methane to the remediation site.

- Permit requirements will differ from state to state.

- Groundwater protection standards (GWPS) have been established as part of a RCRA permit for the M-Area. The GWPS' are based upon EPA Maximum Contaminant Levels (MCLs). Specific goals for contaminants of greater concern are: Compound Concentration (pob)

$\begin{array}{ll}\text { TCE } & 5 \\ \text { PCE } & 5 \\ \text { TCA } & 200\end{array}$

\section{Safety, Risks, Benefits, and Community Reaction}

\section{Worker Safety}

- Health and safety issues for the installation and operation of ISB are essentially equivalent to those for conventional technologies of pump-and-treat or soil vapor extraction.

- Additional permitting and training were required for transportation and delivery of methane and for the operation of the methane injection system.

- Methane concentrations were always far below the explosive limit to minimize any danger to onsite workers. A process hazards review was completed to ensure safe operations.

- Level D personnel protection was used during installation and operation of the system.

\section{Community Safety}

- ISB with an operational offgas treatment system does not produce any significant routine release of contaminants.

- No unusual or significant safety concerns are associated with the transport of equipment, samples, waste, or other materials associated with ISB.

- Careful and thorough monitoring of the subsurface sediments and ground water shows that potential harmful or disease-causing microorganisms are not present or stimulated by ISB at the demonstration site.

\section{Environmental Impacts}

-ISB systems require relatively little space, and use of horizontal wells minimizes clearing and other activities that would be required to install a comparable vertical well network.

- Visual impacts are minor, but operation of the vacuum blower and compressor create moderate noise in the immediate vicinity.

- Nutritional enrichment does not promote the growth of harmful microbes at the demonstration site. 


\section{REGULATORY/POLICY ISSUES continued}

\section{Socioeconomic Impacts and Community Perception}

- ISB has a minimal economic or labor force impact.

- The general public has limited familiarity with ISB; however, the technology received positive support on public visitation days at SRS.

- Bioremediation in general is viewed by the public as a "green" technology, which enhances naturally occurring processes to destroy contaminants. 


\section{Design Issues}

- Gaseous nutrient injection represents a significant new delivery technique for in situ bioremediation.

- Rates of air extraction (or whether to extract at all) and rates of air/nutrient injection must be tailored to site specific needs.

- The bundle-tube pressure sensors installed along Horizontal Wells 1 and 2 to measure injection/extraction efficiency are inexpensive and recommended for future applications.

- Factors that will control injection protocols, remediation system siting, and monitoring include site geology (especially permeability and heterogeneity), concentrations of native nutrients (such as total organic carbon), natural oxidation potential of the subsurface (i.e. aerobic or anaerobic conditions).

- The filter pack on all the horizontal wells is made up of natural formation solids, principally because of collapse around the borehole. This may diminish well efficiencies. Well design must be tailored to the ultimate use of the well. Prepacked screen should only be used if necessary because it adds significantly to the cost.

- A horizontal well in the unsaturated zone removes water from the formation; the water can collect in the well, reducing its effective length. Wells must be designed to channel water away from low areas.

- Careful alignment of the injection and extraction wells is probably not necessary because the zone of influence of the extraction well is far greater than that of the injection well and because subsurface heterogeneities strongly influence air flow.

\section{Implementation Considerations}

- Separate components of the system may be utilized for a particular application or the system may be used in tolal as demonstrated at the Savannah River Site.

- For example, the system can be used with or without horizontal wells.

- Another option involves design of a system that does not have the vapor extraction component. In this case, biodegradation of contaminants is optimized but no contaminants are removed via a physical process.

- At some sites the addition of methane may not be required at all or at least initially, because there is naturally a sufficient carbon source for the indigenous methanotrophs.

- The optimum operating campaign involved pulsed injection of methane $(4 \%)$ combined with continuous injection of air with nutrients (nitrogen and phosphorus).

- Automated control and monitoring functions added significantly to the ease and cost of operation of the system.

- A pulsing regime for the gaseous nutrients can be designed to accomplish both aerobic and anaerobic degradation simultaneousIy. For example, at SRS both TCE and PCE were biodegraded. This required both aerobic and anaerobic degradation. It is believed that anaerobic pockets were created in the subsurface, which led to degradation of PCE within an overall aerobic system.

- Horizontal drilling methods must be tailored to specific site conditions with special considerations for the type of drilling fluid, drilling bit, drilling methodology, casing installation, etc.

\section{Technology Limitations/Needs for Future Development}

- Long-term performance data from several years of operation varying operating parameters are required to assess the need for design improvements and to better quantify life-cycle costs.

- Better monitoring methods for determining mass balance and microbiological health of the subsurface population are required to facilitate implementation of ISB.

- It is possible that subsurface injection of gases below the water table can induce ground water flow. In such a case, ISB could accelerate lateral migration of contaminants in certain geologic settings. If clay layers or other geologic features constrict vertical flow, it may be necessary to use ISB in conjunction with a pump-and-treat system for hydraulic control.

- There was no evidence of plugging of the wells as a result of the increased subsurface biomass that resulted from the subsurface injection of nutrient gases.

- More experience with environmental horizontal drilling under a variety of subsurface conditions will ensure better well installations at reduced costs. 


\section{Technology Selection Considerations}

- The cost of adding methane injection to an air sparging system is relatively low and easily recovered (nearly all water samples showed greater than $90 \%$ mineralization of TCE and PCE by methanotrophs after nutrients were added to the system).

- This technology yields significant economic and efficiency gains over conventional baseline technologies for remediation of ground water and sediment contaminated with chlorinated solvents.

- One application of the ISB system can be as a polishing technique after high concentrations are removed by in Situ Air Stripping using horizontal wells. This approach would likely be used at sites where initial contaminant concentrations are high. On the other hand, the biological component may be most effective at sites with lower contaminant concentrations, ultimately targeting attainment of drinking water thresholds.

- The role of horizontal wells in improving the efficiency of remediation was assessed. Remediation efficiency may be enhanced by increased surface area for reaction, similarity of well profile and contaminant plume geometry, borehole access to areas beneath existing facilities, and drilling along facility boundaries to control plume migration. However, each site must be assessed for the utility of horizontal wells.

- Successful ISB requires good contact between injected air and contaminated soils and ground water. An optimal geologic setting would have moderate to high saturated soil permeability, a fairly homogeneous saturated zone to allow for effective injection of gaseous nutrients, and sufficient saturated thickness. Vadose zone characteristics would be moderate to high permeability and homogeneity.

- ISB using horizontal wells may be most applicable in linearly shaped plumes that are relatively thin. 


\section{Site History/Background}

- The Savannah River Site's historical mission has been to support national defense efforts through the production of nuclear materials. Production and associated research activities have resulted in the generation of hazardous waste by-products now managed as 266 waste management units located throughout the 300 mile $^{2}$ facility.

- The A and M Areas at Savannah River have been the site of administrative buildings and manufacturing operations, respectively. The A/M-Area is approximately one mile inward from the northeast boundary of the $\mathbf{3 0 0}$ mile$^{2}$ Savannah River Site. Adjacent to the site boundary are rural and farming communities. Specific manufacturing operations within the $M$ Area included aluminum forming and metal finishing.

- The M-Area operations resulted in the release of process wastewater containing an estimated 3.5 million lbs. of solvents. From 1958 to $1985,2.2$ million lbs. were sent to an unlined settling basin, which is the main feature of the M-Area Hazardous Waste Management Facility (HWMF). The remaining 1.3 million lbs. were discharged from Outfall A-014 to Tim's Branch, a nearby stream, primarily during the years 1954 to 1982.

- Discovery of contamination adjacent to the settling basin in 1981 initiated a site assessment effort eventually involving approximately 250 monitoring wells over a broad area. A pilot ground water remediation system began operation in February 1983. Full-scale ground water treatment began in September 1985.

- High levels of residual solvent are found in the soil and ground water near the original discharge locations. Technologies to augment the pump-and-treat efforts, for example soil vapor extraction, ISAS, and bioremediation, have been tested and are being added to the permitted corrective action.

\section{Contaminants of Concern}

Contaminants of greatest concern are:

1,1,2-trichloroethylene (TCE)

tetrachloroethylene (PCE)

1,1,1-trichloroethane (TCA)

\begin{tabular}{|c|c|c|c|c|}
\hline Property at STP & Units & TCE & PCE & TCA \\
\hline $\begin{array}{l}\text { Empirical Formula } \\
\text { Density }\end{array}$ & $\mathrm{g} / \mathrm{cm}^{3}$ & $\begin{array}{l}\mathrm{COH}=\mathrm{CO} 2 \\
1.46\end{array}$ & $\begin{array}{l}\mathrm{C}_{2} \mathrm{C}=\mathrm{COC}_{2} \\
1.62\end{array}$ & $\begin{array}{l}\mathrm{CH}_{3} \mathrm{CCH}_{3} \\
1.31\end{array}$ \\
\hline Vapor Pressure & $\mathrm{mmHg}$ & 73 & 19 & 124 \\
\hline $\begin{array}{l}\text { Henry's Law } \\
\text { Constant }\end{array}$ & am:m3/mole & $9.9 \mathrm{E}-3$ & $2.9 E-3$ & $1.6 \mathrm{E}-2$ \\
\hline Water Solubility & $\mathrm{mg} / \mathrm{L}$ & $1000-1470$ & $150-485$ & $300-1334$ \\
\hline $\begin{array}{l}\text { Octanol-Water } \\
\text { Partifion } \\
\text { Coefficient: Kow }\end{array}$ & $\cdot$ & 195 & 126 & 148 \\
\hline
\end{tabular}

\section{Nature and Extent of Contamination}

- Approximately $71 \%$ of the total mass of VOCs released to both the settling basin and Tim's Branch was PCE, $28 \%$ was TCE, and $1 \%$ was TCA.

- The estimated amount of dissolved organic solvents in ground water in concentrations greater than $10 \mathrm{ppb}$ is between 260,000 and $450,000 \mathrm{lbs}$ and is estimated to be $75 \%$ TCE. This estimate does not include contaminants sorbed to solids in the saturated zone or in the vadose zone. The area of VOC-contaminated ground water has an approximate thickness of 150 feet, covers about 1200 acres, and contains contaminant concentrations greater than $50,000 \mathrm{ug} / \mathrm{L}$.

- DNAPLs found in 1991 present challenges for long-term remediation efforts.

- Vadose zone contamination is mainly limited to a linear zone associated with the leaking process sewer line, solvent storage tank area, settling basin, and the A-014 outfall at Tim's Branch. 


\section{APPENDIX B}

\section{TECHNOLOGY DESCRIPTION DETAIL}

\section{System Configuration}

- Wells $1 \& 2$ are paired wells targeting contaminated sands. They are semiparallel in the subsurface, one in the vadose zone and one in the saturated zone.

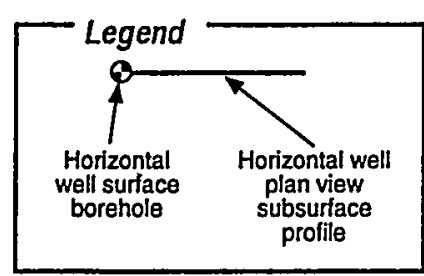

\section{inom}

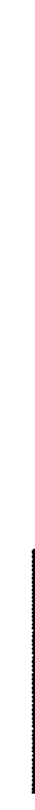

Abandoned

Process Sewer

Lino

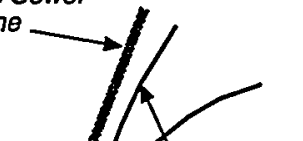

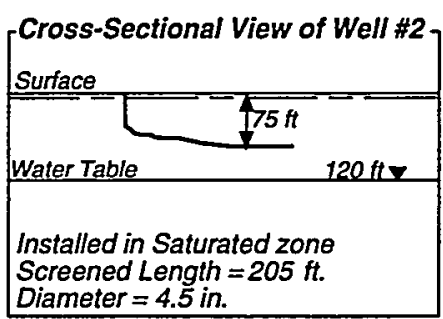
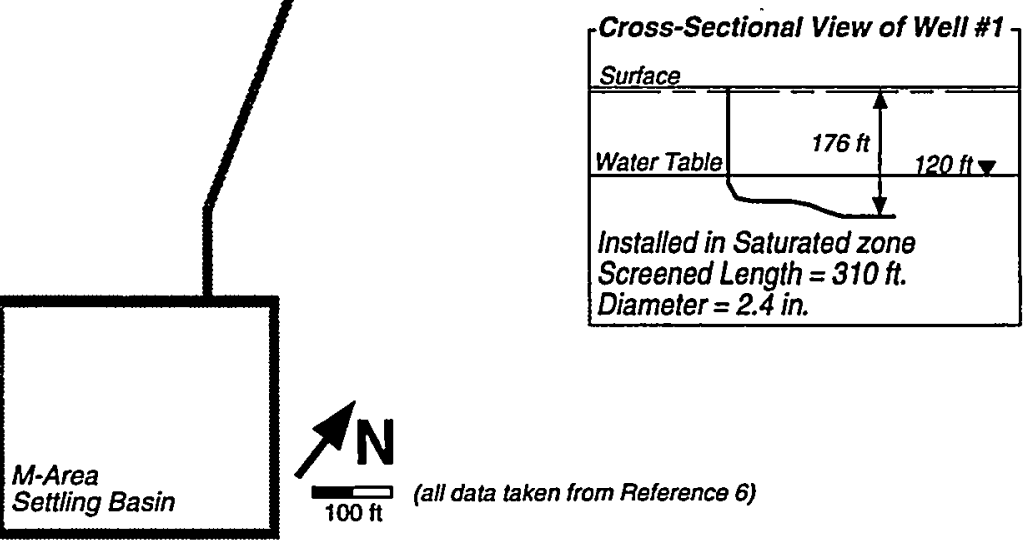

\section{Horizontal Well Close-Ups}

\section{Well \# 1}

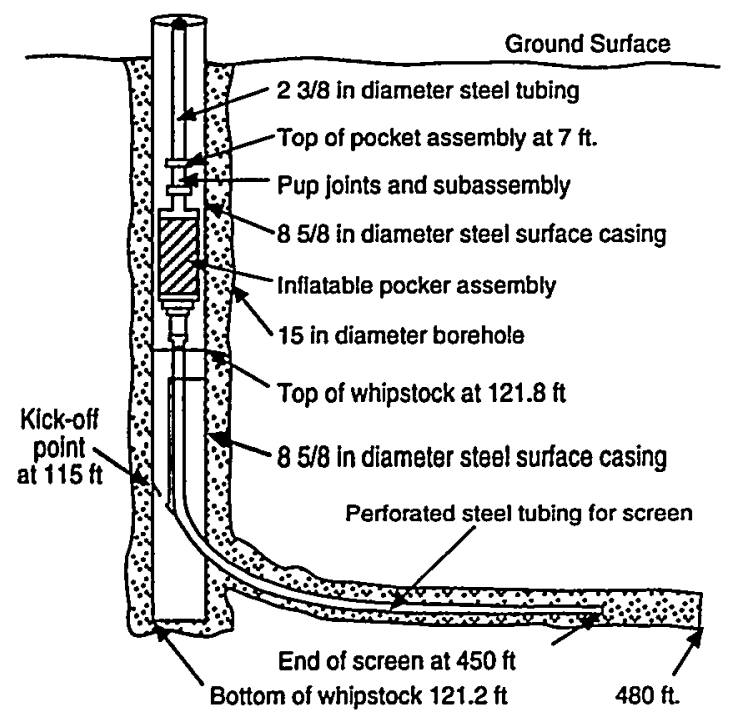

\section{Well \# 2}

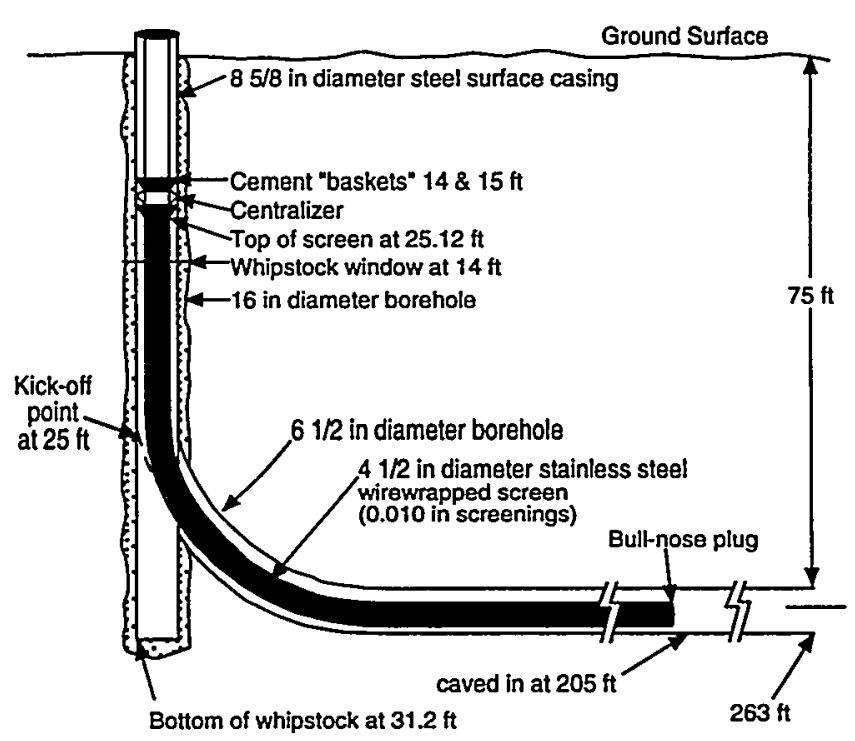




\section{Horizontal Well Installation Techniques}

The techniques used to directionally drill and install a horizontal well depend on the location and purpose of the well. Petroleum industry technology was used to install Wells 1 and 2 at the Savannah River Site; however, this technology is no longer used. Current installation techniques include the following:

1. Pipeline/Utility River Crossing System-Based on a mud rotary system used to drive a downhole drill assembly, including a drilling tool, a hydraulic spud jet with a 2-degree bend to provide directional drilling or a downhole motor depending on the lithology to be drilled.

2. Utility Industry Compaction System -Down hole drill assembly consists of a wedge-shaped drilling tool and a flexible subassembly attached to the drill string. The borehole is advanced by compaction, forcing cuttings into the borehole wall. Reduced volumes of water are introduced to cool the drill bit; no circulation of drilling fluid is accomplished.

3. Hybrid Petroleum Industry/Utility Industry Technology - Modified mud rotary system with bottom hole assembly comprised of a survey tool, steerable downhole motor, and expandable-wing drill bit. Drilling fluids are used. Curve is drilled and pipe is installed in curve before horizontal is drilled. Only one company provides this type of drilling system.

\section{Operational Requirements}

- Design and management of ISB systems require expertise in environmental, chemical, mechanical, and civil engineering as well as hydrogeology and environmental regulations. Automation of system operations with a real-time problem notification system reduced the manpower requirements significantly over that required for the earlier in situ air stripping demonstration. Operation of multiple systems of the scale implemented at the Savannah River Site can be performed by a $1 / 6$ full-time equivalent technician per system. Larger systems or extensive monitoring activities would require additional staff.

\section{Monitoring Systems}

Monitoring wells and vadose zone piezometers had previously been installed at the site for the ISAS demonstration.

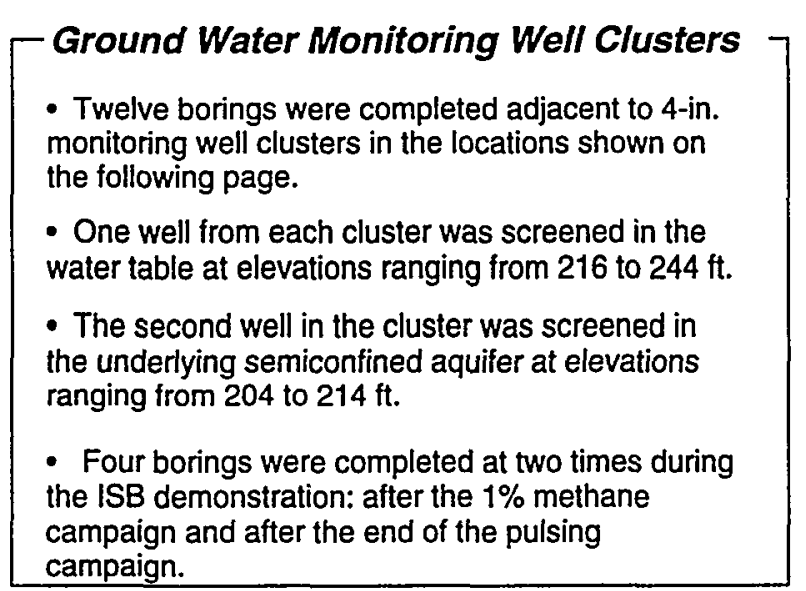

\section{Vadose Zone Piezometer Clusters}

- Three borings were cored adjacent to piezometer clusters in the vadose zone.

- Three piezometer tubes having lengths of approximately $52 \mathrm{ft}, 77 \mathrm{ft}$ and $100 \mathrm{ft}$ were installed into each borehole.

\section{- Geophysical Monitoring}

- ERT was performed in five borings. ERT maps the behavior of subsurface fluids as they change in response to natural or remedial processes.

- Several single-point flow sensors were placed between the injection and extraction wells just below the water table) to measure ground water flow in the area most affected by the ISB process. 


\section{Monitoring Systems (continued)}

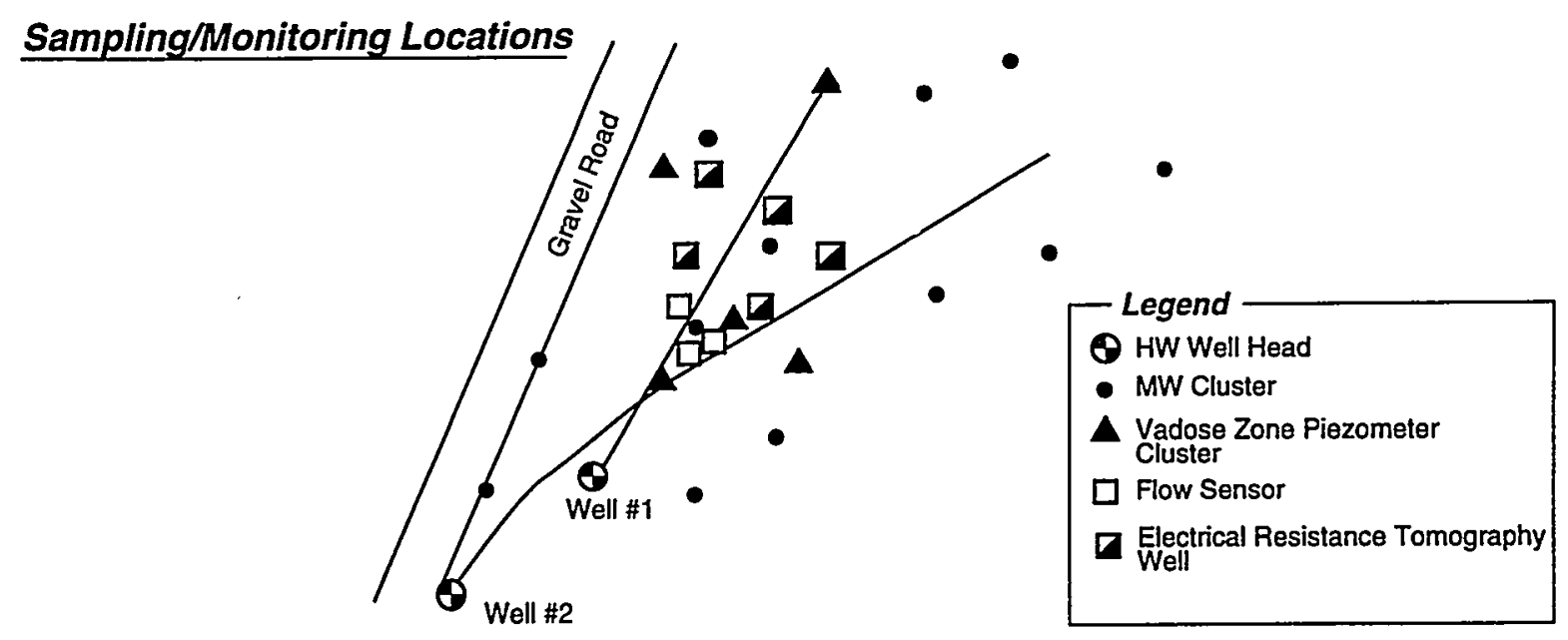

\section{Bundle Tubes}

Each horizontal well was filled with a bundle of six tubes encased in a perforated pipe or well screen. Each tube terminated at a discrete distance from the surface for sampling or monitoring at different locations along the well bore.

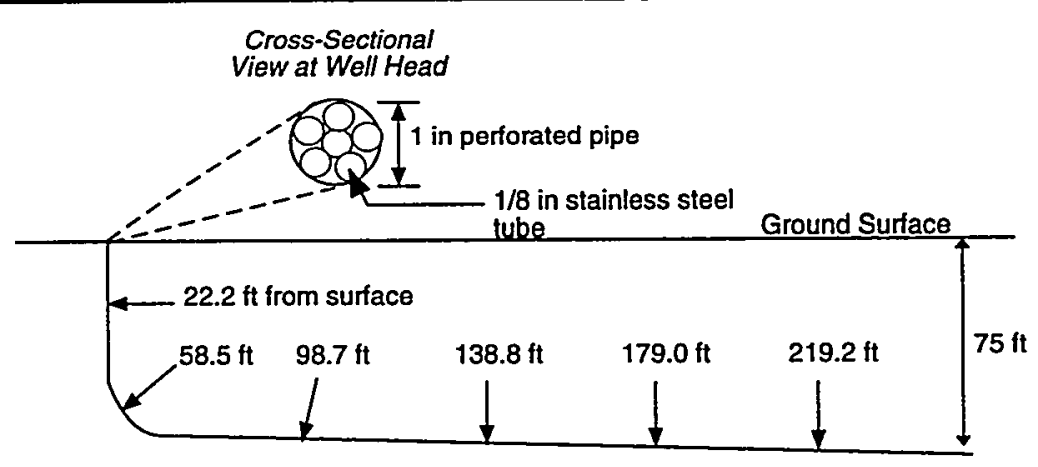




\section{APPENDIX C}

\section{PERFORMANCE DETAIL}

\section{Operational Performance}

\section{Maintainability and Reliability}

- No functional problems encountered during demonstration; system was operational approximately $90 \%$ of all available time.

- Operational performance over long periods (years) not yet available.

\section{Operational Simplicity}

- Monitoring performance of ISB is more difficult than monitoring performance of baseline pump-andtreat technology; however, systems have been automated and can be operated and maintained in the field typically by $1 / 6$ full-time equivalent technician. Staffing requirements are detailed in Appendix B.

\section{Demonstration Schedule}

\section{Major Milestones of the Demonstration Program}

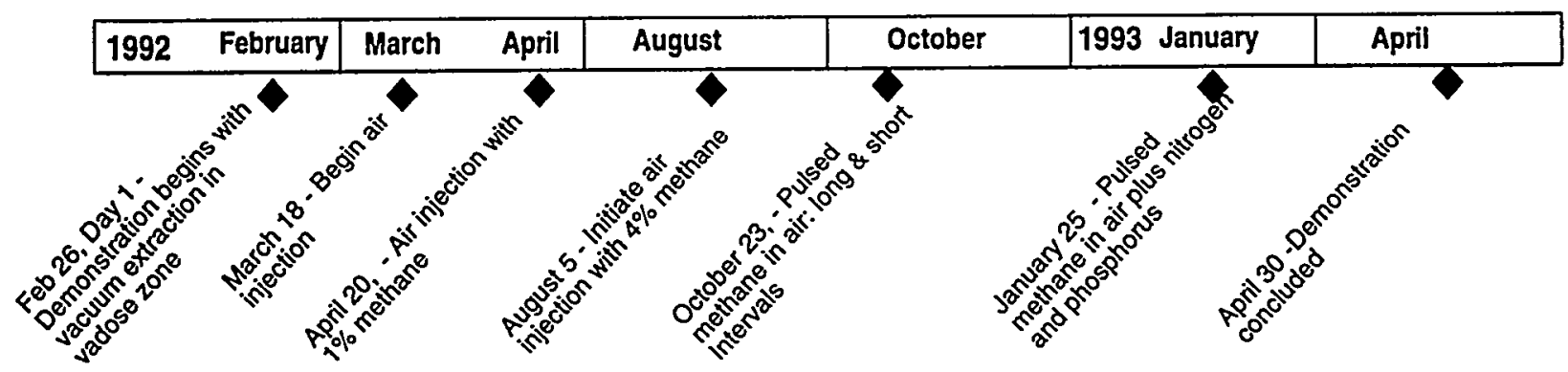

\section{Sampling, Monitoring, Analysis, and QA/QC Issues}

\section{Objectives}

- Gather baseline information and fully characterize site

- Evaluate removal efficiencies with time

- Evaluate subsurface microbial ecologies

- Identify and evaluate zones of influence

\section{Baseline Characterization}

- Baseline characterization was performed before the demonstration to gather information on the geology, geochemistry, hydrology, and microbiology of the site. The distribution of contaminants in soils and sediments in the unsaturated zone and ground water was emphasized. These data were compared with data on soil collected during and after the demonstration to evaluate the effectiveness of ISB.

- Continuous cores were collected adjacent to monitoring well and vadose zone boreholes. Sediments for VOC analysis were collected at 5 -ft intervals and at major lithology changes. Samples for microbiological characterization were collected every $10 \mathrm{ft}$.

- Water samples were collected and analyzed for VOC content and microbial characteristics from monitoring well clusters and at discrete depths adjacent to monitoring well clusters.

- Geologic cross-sections were prepared using gamma ray, sp, resistivity, density, and neutron geophysical logs and core logs. 


\section{Sampling, Monitoring, Analysis, and QAVC Issues (continued)}

\begin{tabular}{|c|c|c|c|}
\hline Sampling \& Monitoring & Location(s) & Frëqueñoy & (n)chnique \\
\hline Pressure Monitoring & $\begin{array}{l}\text { vadose zone piezometers } \\
\text { injection well }\end{array}$ & $\begin{array}{l}\text { weekly } \\
2 \times \text { daily }\end{array}$ & $\begin{array}{l}\text { measured at surface using magnehelic or } \\
\text { slack-tube macrometer } \\
\text { measured at wellhead using pressure gauge }\end{array}$ \\
\hline Vacuum Monitoring & $\begin{array}{l}\text { extraction well } \\
\text { extraction well bundle tubes }\end{array}$ & $\begin{array}{l}2 \times \text { daily } \\
\text { weekly }\end{array}$ & $\begin{array}{l}\text { measured at wellhead using vacuum gauge } \\
\text { measured at surface }\end{array}$ \\
\hline Vapor Sampling & $\begin{array}{l}\text { vadose zone piezometers } \\
\text { extraction well } \\
\text { bundle tube }\end{array}$ & $\begin{array}{l}\text { weekly } \\
2 \times \text { daily } \\
\text { weekly }\end{array}$ & $\begin{array}{l}\text { sampled through a septum on the vacuum side } \\
\text { bf a vacuum pump using gas-tight syringes } \\
\text { same as above } \\
\text { pame as above. }\end{array}$ \\
\hline $\begin{array}{l}\text { Ground Water } \\
\text { Sampling }\end{array}$ & monitoring well clusters & biweekly & $\begin{array}{l}\text { sampled using documented Savannah River } \\
\text { Site (SRS) well sampling protocols }\end{array}$ \\
\hline $\begin{array}{l}\text { Microbiological } \\
\text { Sampling }\end{array}$ & monitoring well clusters & biweekly & $\begin{array}{l}\text { sampled using documented SRS well } \\
\text { sampling protocols }\end{array}$ \\
\hline Helium Tracer Test & $\begin{array}{l}\text { vadose zone piezometers } \\
\text { extraction well }\end{array}$ & $\begin{array}{l}\text { weekly } \\
2 \times \text { daily }\end{array}$ & $\begin{array}{l}\text { sampled using 500-ml disposable syringes } \\
\text { and transferred to } 30-\mathrm{ml} \text { preevacuated serum } \\
\text { vials }\end{array}$ \\
\hline
\end{tabular}

\section{Analytical Methods and Equipment}

- Vapor grab samples were analyzed in the field using both a Photo Vac field gas chromatograph (GC) and a GC fitted with flame ionization and electron capture detectors. Analysis was performed immediately after collection.

- Bulk water parameters, including temperature, $\mathrm{pH}$, disşolved oxygen, conductivity, and oxidation reduction potential, were measured using a Hydrolab.

- VOC analysis of water and sediment samples was performed on-site using an improved quantitative headspace method developed by Westinghouse Savannah River Company. Analyses were performed on an HP-5890 GC fitted with an electron capture detector and headspace sampler.

- Helium tracer samples were analyzed using a helium mass spectrometer modified to sample serum vials at a constant rate.

\section{QAVQC Issues}

- Vapor samples were analyzed immediately after collection and GC analysis of soil and water samples were completed less than 3 weeks after collection.

- Duplicate analysis was performed for nearly every water and sediment sample collected.

- Approximately 161 samples were analyzed off-site using standard EPA methods to corroborate onsite testing which used the improved quantitative headspace method described earlier. Crosscomparison showed that the quantitative headspace analysis generated equivalent to superior data.

- GC calibration checks were run daily using samples spiked with standard solutions.

\section{Performance Validation}

- Samples analyzed onsite by nonstandard EPA methods were sent offsite for confirmatory analysis using EPA methods. Results from these analyses confirmed the findings of Savannah River efforts.

- The effectiveness of horizontal wells for environmental cleanup has been demonstrated by their use in vapor extraction and ground water/free product recovery systems which are also discussed in Appendix D. 


\section{APPENDIX D \\ COMMERCIALIZATION/NTELLECTUAL PROPERTY}

\section{Intellectual Property}

\section{Primary Sponsor}

U.S. Department of Energy, Office of Environmental Management, Office of Technology Development

\section{Existing/Pending Patents}

Several parties, including national laboratories, industry, academia, EPA, USGS, USAF, participated in the development and implementation of the ISB system. These participants are listed on the next page.

- Patent 5,326,703, "Method and System for Enhancing Microbial Motility," T.C. Hazen and G. Lopez de Victoria, assignors to the U.S. as represented by the U.S. DOE.

-Patent 5,324,661, "Chemotactic Selection of Pollutant Degrading Soil Bacteria," T.C. Hazen, assignors to the U.S. as represented by the U.S. DOE.

- Patent 5,384,048, "Bioremediation of Contaminated Groundwater," T.C. Hazen and C.B. Fliermans, assignors to the U.S. as represented by the U.S. DOE.

-Patent Submitted 2/94, "Contactor System for Phosphorus Addition to Support Gas Phase Environmental Bioremediation," B.B. Looney, T.C. Hazen, S. Pfiffner, and K. Lombard.

\section{Related patents include:}

- Patent 4,832,122, "In Situ Remediation System and Method for Contaminated Groundwater," J.C. Corey, B.B. Looney, and D.S. Kaback, assignors to the U.S. as represented by the U.S. DOE.

- Patent 5,186,255, "Flow Monitoring and Control System for Injection Wells," J.C. Corey, assignor to the U.S. as represented by the U.S. DOE.

- Patent 5,263,795, "In Situ Remediation System for Groundwater and Soils," J.C. Corey, D.S. Kaback, and B.B. Looney, assignors to the U.S. as represented by the U.S. DOE.

-Patent 4,660,639, "Removal of Volatile Contaminants from the Vadose Aone of Contaminated Ground," M.J. Visser and J.D. Malot, assignors to the Upjohn Company. WSRC paid a one-time license fee to the assignee for the use of the process with horizontal wells.

-Patent 5,006,250, "Pulsing of Electron Donor and Electron Acceptor for Enhanced Biotransformation of Chemicals, " P.V. Roberts, G.D. Hopkins, L. Semprini, P.L. McCarty, and D.M. McKay, assignors to the Board of Trustees of the Leland Stanford Junior University.

\section{Licensing Information}

-ISBR is commercially available through the WSRD Technology Transfer Office -To date, 19 licenses have been applied for and six licenses have been granted. 


\section{Government}

U.S. Department of Energy

Savannah River Site

Oak Ridge National Laboratory

Hazardous Waste Remedial Actions Program

Idaho National Engineering Laboratory

Pacific Northwest Laboratory

Lawrence Livermore National Laboratory

Los Alamos National Laboratory

U.S. Environmental Protection Agency

U.S. Geological Survey

U.S. Air Force

U.S. Army Corps of Engineers

South Carolina Department of Health and Environmental Control

\section{Academia}

Stanford University

University of South Carolina

University of Illinois

University of Washington

Utah State University

Georgia State University

University of Minnesota

University of Cincinnati

\section{Industry}

Gas Research Institute

Radian Corp.

Eastman Christiensen

Westinghouse

E. I. duPont de Nemours Inc.

Michigan Biotech Institute

Envirex Inc.

Bechtel Inc.

Graves

O'Brien and Gere

Monitoring Testing Senvice

General Engineering Lab

Tren Fuels

South Carolina Electric and Gas Co.

Terra-Vac 


\section{APPENDIX E}

\section{REFERENCES}

1. T. C. Hazen 1991. Test Plan for In Situ Bioremediation Demonstration of the Savannah River Integrated Demonstration Project, DOEJOTD TTP No.:SR 0566-01. WSRC-RD-91-23. 88 pp., WSRC Information Services, Aiken, SC.

2. T. C. Hazen 1993. Preliminary Technology Report for In Situ Bioremediation Demonstration (Methane Biostimulation) of the Savannah River Site Integrated Demonstration Project, DOE/OTD. WSRC-TR-93-670. 39 pp. WSRC Information Services, Aiken, SC.

3. T. C. Hazen 1995. Level 2 Summary Technology Report for In Situ Bioremediation Demonstration (Methane Biostimulation) of the Savannah River Site Integrated Demonstration Project, DOE/OTD. in press.

4. D. S. Kaback, B. B. Looney, J. C. Corey, and L. M. Wright, III 1989. Well Completion Report on Installation of Horizontal Wells for In Situ Remediation Tests. WSRC-RP-89-784. Westinghouse Savannah River Company, Aiken, SC.

5. R. P. Saaty and S. R. Booth 1994. In Situ Bioremediation: Cost Effectiveness of a Remediation Technology Field Test at the Savannah River integrated Demonstration Site. Los Alamos National Laboratory report No. LA-UR-94-1714.

6. B. J. Travis and N. D. Rosenberg 1994. Numerical Simulations in Support of the In Situ Bioremediation Demonstration at Savannah River. 43p. Los Alamos National Laboratory Technical Report: LA-UR94-716.

7. Batelle Pacific Northwest Laboratories 1994 . PROTECH Technology Information Profile for In Situ Bioremediation, PROTECH database.

8. Science Applications International Corporation 1993.Tumover Plan for the Integrated Demonstration Project for Cleanup of Contaminants in Soils and Groundwater at Non-Arid Sites, SRS.

9. D. D. Wilson and D. S. Kaback 1993, Industry Survey for Horizontal Wells, WSRC-TR-93-511. WSRC Information Senvices, Aiken, SC.

10. C. A. Eddy Dilek et al. 1993. Post-Test Evaluation of the Geology, Geochemistry, Microbiology, and Hydrogeology of the In Situ Air Stripping Demonstration Site at the Savannah River Site. WSRC-TR-93-369 Rev.0. WSRC Information Services, Aiken SC.

11. E.l.duPont de Nemours 1982. Preliminary Technical Data Summary M-Area Groundwater Cleanup Facility, Savannah River Laboratory.

12. A. L. Ramirez and W. D. Daily 1995. Electrical Resistance Tomography During in Situ TCE Remediation at the Savannah River Site, Joumal of Applied Geophysics.

13. Martin Marietta Hazwrap in conjunction with Stone and Webster and CKY 1995. (prepared for the U.S. Department of Energy) In Situ Air Stripping Using Horizontal Wells, Innovative Technology Summary Report. 